\title{
Бібліографія References
}

1. Council for Exceptional Children. (2008). What Every Special Educator Must Know: Ethics, standards, and guidelines $\left(6^{\text {th }}\right.$ ed. revised). Arlington, VA: Author. 286 p. 2. Duchan, J.F. Elizabeth E. Farrell. 18701932. Retrieved from: https://www.acsu.buffalo.edu/ duchan/ new_history/hist19c/subpages/farrell.html;_2. Education for All Handicapped Children Act (EAHCA) (1975). Public Law 94-142. Retrieved from: http://www.gpo.gov/fdsys/pkg/ STATUTE-89/pdf/STATUTE-89-g773.pdf.; 3. Individuals with Disabilities Education Act (IDEA)) (2004). Retrieved from: https://www.gpo.gov/fdsys/pkg/USCODE-2011-title20/pdf/USCODE2011-title20-chap33. ; 4. Kauffman, J. M., Hallahan, D. P., and Pullen, P. C. (Eds.) (2011) Handbook of Special Education, Second Edition, New York: Routledge. 369 p.; 5. Kode, K. (2017). Elizabeth Farrell and the History of Special Education. Washington: Council for Exceptional Children. 88p.; 4. Kode, K. (2001). Guarding the sacred fires: Elizabeth E. Farrell's contributions to the creation of special education in New York City. Dissertations $\quad(1962 \quad-\quad$ 2010). Retrieved from: https://epublications.marquette.edu/dissertations/ AAI3049933.

Received 01.11.2019 Accepted 28.121.2019

УДК: 159.955.6-047.44:373-056.313

DOI 10.32626/2413-2578.2020-15.176-186

Рябець С.

elizabeth.r.e.n.k@gmail.com

Гаврилов О.

kafiogoped@ukr.net

https://orcid.org/0000-0003-0811-2130

\section{ТЕНДЕНЩІЇ РОЗВИТКУ САМООЦНКИ ДІТЕЙ 3 ІНТЕЛЕКТУАЛЬНОЮ НЕДОСТАТНІСТЮ НА РІЗНИХ ЕТАПАХ ШКІЛЬНОГО НАВЧАННЯ}

Відомості про автора: Рябець Єлизавета, магістрант кафедри логопедії та спеціальних методик факультету корекційної та соціальної педагогіки і психології Кам'янець - Подільського національного університету імені Івана Огієнка. E-mail: elizabeth.r.e.n.k@gmail.com. Гаврилов Олексій, кандидат психологічних наук, доцент, завідувач кафедри логопедії та спеціальних методик факультету корекційної та

(C) Рябець Є., Гаврилов О. 
соціальної педагогіки і психології Кам'янець-Подільського національного університету імені Івана Огієнка. E-mail: kafiogoped@ukr.net

Contact: Elizabeth Riabets, undergraduate of Chair of Speech Therapy and Special methods in the Correctional and Social Pedagogy and Psychology Department of Kamyanets-Podilskyi National Ivan Ohienko University. Email: elizabeth.r.e.n.k@gmail.com. Gavrilov Oleksiy, Ph.D. of psychology, assistant professor, Head of Chair of Speech Therapy and Special methods in the Correctional and Social Pedagogy and Psychology Department of Kamyanets-Podilskyi National Ivan Ohienko University. E-mail: kafiogoped@ukr.net

Відомості про наявність друкованих праць:_рикладна корекційна психопедагогіка: олігофренопедагогіка / За ред. О.В. Гаврилова. Кам'янець-Подільський: ТОВ «Друк-Сервіс», 2017. 600 с. Гаврилов О. До питання про розумову відсталість як психолого-педагогічну проблему // Збірник наукових праць Кам'янець-Подільського національного університету імені Івана Огієнка / за ред. О.В. Гаврилова, B.I. Співака. Випуск XXI Кам'янець-Подільський: Медобори-2006, Аксіома, 2012. С. 44-55.

Рябець Є., Гаврилов О. Тенденції розвитку самооцінки дітей 3 інтелектуальною недостатністю на різних етапах шкільного навчання. Статтю присвячено комплексному вивченню стану самооцінки дітей 3 інтелектуальною недостатністю на різних етапах шкільного навчання (початкова, середня та старша школа). Висвітлено поняття самооцінки, та вказано загальну тенденцію розвитку стану самооцінювання дітей з інтелектуальною недостатністю на кожній ланці навчання на основі наявних досліджень 3 даного питання.

Розроблено дослідження 3 метою визначення рівня самооцінки учнів на рівні початкової, середньої та старшої школи, та висвітлення загальних тенденцій становлення оцінювання власної особи учнів впродовж всього навчання на основі двох методик - «Дерево» (авт. Д. Лампена), та «Сходинки» (авт. В. Щур). Висвітлено результати дослідження 3 кількісними показниками у вигляді графіків та відсоткових відношень, та графіків - показників тенденції становлення самооцінки за двома методиками.

3'ясовано загальні закономірності розвитку вміння оцінювати себе учнями, та причини, які можуть сприяти та перешкоджати даному процесу, вказується роль педагогічного колективу у формуванні адекватного самооцінювання учня з інтелектуальною недостатністю, та підтримання цього рівня на усіх ланках навчання. 
Ключові слова: самооцінка, інтелектуальна недостатність, завищена, знижена, адекватна самооцінка, ланки навчання, тенденції становлення.

Рябец Е., Гаврилов А. Тенденции развития самооценки детей с интеллектуальной недостаточностью на разных этапах школьного обучения. Статья посвящена комплексному изучению состояния самооценки детей с интеллектуальной недостаточностью на разных этапах школьного обучения (начальная, средняя и старшая школа). Освещены понятие самооценки, и указано общую тенденцию развития состояния самооценки детей с интеллектуальной недостаточностью на каждом звене обучения на основе имеющихся исследований по данному вопросу.

Разработано исследования с целью определения уровня самооценки учащихся на уровне начальной, средней и старшей школы, и освещение общих тенденций становления оценки собственной личности учащихся в течение всего обучения на основе двух методик - «Дерево» (авт. Д. Лампена) и «Ступеньки» (авт. В. Щур). Представлены результаты исследования по количественным показателям в виде графиков и процентных соотношений, и графиков - показателей тенденции становления самооценки по двум методикам.

Выяснено общие закономерности развития умения оценивать себя учениками, и причины, которые могут способствовать и препятствовать данному процессу, указывается роль педагогического коллектива в формировании адекватной самооценки ученика с интеллектуальной недостаточностью, и поддержание этого уровня на всех звеньях обучения.

Ключевые слова: самооценка, интеллектуальная недостаточность, повышенная, пониженная, адекватная самооценка, звенья обучения, тенденции становления.

Riabets E., Havrylov O. Trends in the development of self-esteem of children with intellectual disabilities at different stages of schooling. The article reveals the concept of "self-esteem", general patterns, peculiarities of its formation in children with intellectual disabilities, and tendencies of development of self-esteem of students of this category at different levels of schooling. Article is devoted to the complex study of the self-esteem status of children with intellectual disability at different stages of school education (elementary, middle and high school). The concept of self-esteem is covered, and the general tendency of development of self-esteem of children with intellectual disability at each level of study based on available research on this issue indicated. An analysis of the work of scholars involved in this issue and their indication, that in order for a child with intellectual disability to be better able to adapt to the school space and overcome difficulties, that arise during 
the educational process, it is necessary to keep a positive image of themselves, and to develop their skills and abilities in each of the classes in which the child learns.

A study was developed to determine students 'self-esteem levels at primary, secondary, and high school levels, and to elucidate the general tendencies of students' self-assessment during the entire study based on two methods, the «Tree» (edited by D. Lampen) and the «Steps» (by W. Shchur). The results of the study presented with quantitative indicators in the form of graphs and percentages, and graphs - indicators of the tendency of self-esteem formation by two methods.

The general laws of development of the ability to evaluate themselves as learners are clarified, and the reasons that can contribute to and hinder this process, the role of the pedagogical team in the formation of adequate selfassessment of the student with intellectual disability, and maintaining this level at all links of learning is indicated.

Keywords: self-esteem, intellectual insufficiency, overestimated, reduced, adequate self-esteem, links of learning, tendencies of formation.

Актуальність дослідження. Самооцінка $\epsilon$ однією 3 структур особистості, яка вирішує проблеми ії становлення, відношення до своєї діяльності та іiі оцінки, уміння робити висновки та виправляти помилки як у роботі, так і поведінці. Актуальність проблеми становлення самооцінювання дитини з інтелектуальною недостатністю продиктовано тим, що дана психологічна структура впливає на усесторонній розвиток дитини даної категорії, $є$ певним регулятором поведінки, діяльності та встановлення відносин з іншими людьми, що, в свою чергу, впливає на іiі подальшу соціалізацію, вміння критично мислити, та коригувати свої помилки.

Аналіз останніх досліджень. Самооцінка - це особистісне новоутворення, що має провідну роль у формуванні особистості дитини як 3 типовим, так і 3 порушеним розвитком. Від неї залежать усвідомлення власної особи, рівень вимогливості до своєї діяльності, рівень самокритики та майбутня соціальна значимість дитини.

Аналіз робіт вчених, які займались питанням самооцінки учнів 3 інтелектуальною недостатністю (Б. Ананьєв, А. Зак, М. Матвєєва, В. Синьов, О. Хохліна, Т. Шибутані та ін.) $[1,2,3,4,5]$ дозволяє зазначити, що вони вважають самооцінку цінністю та значимістю, якою дитина сама себе наділяє, а також окремі сторони своєї особистості та поведінки. Вони вказують, що для того, щоб дитина 3 інтелектуальною недостатністю була здатна краще адаптуватися до шкільного простору $\mathrm{i}$ долати труднощі, які виникають під час навчального процесу, їй необхідно зберігати позитивне уявлення про себе та розвивати свої 
вміння та здібності на кожному з щаблів шкільного навчання, тобто, формувати адекватну самооцінку [4].

Дослідження вказують на те, що становлення самооцінки дитини 3 інтелектуальною недостатністю у закладі шкільної освіти має наступну тенденцію: молодший шкільний вік - неадекватний рівень самооцінки: переважно завищена; середній шкільний вік - найбільш адекватний рівень самооцінювання; старший шкільний вік - неадекватний рівень самооцінки: від завищеної до зниженої [3].

При цьому зазначаємо, що важлива, часто визначна роль в формуванні стійкої адекватної самооцінки дітей даної групи належить педагогам, особливо - класному керівнику, який постійно взаємодіє 3 дітьми та батьками [2]. Здійснюючи навчально-виховний процес, проводячи оцінку поведінки, навчальної діяльності дітей, педагогічний колектив здійснює так званий «направляючий вплив» на формування оцінки власної особистості, адже вона багато в чому опирається на слова та оцінку дорослих. Це, в свою чергу, зумовлює необхідність створення сприятливого «клімату» у класі задля формування адекватного рівня самооцінки, що продиктовано залежністю думки дитини з порушеннями інтелектуального розвитку від думки оточуючих.

Задля перевірки та опису даних про тенденції становлення самооцінки дітей з інтелектуальною недостатністю нами було проведено дослідження, спрямоване на визначення динаміки формування та розвитку самооцінки дітей даної категорії на різних етапах шкільного навчання.

Мета дослідження - виявлення особливостей динаміки формування самооцінки учнів з інтелектуальними порушеннями легкого ступеня на кожному етапі шкільного навчання;

Виклад основного матеріалу. Задля перевірки та опису даних про тенденції становлення самооцінки дітей 3 інтелектуальними порушеннями легкого ступеня було проведено дослідження, спрямоване на визначення динаміки формування та розвитку самооцінки дітей даної категорії на різних етапах шкільного навчання. Всього у дослідженні приймало участь 78 учнів (серед них: 33 учні початкових класів спеціального закладу шкільної освіти, 31 учень - середніх, 14 - старших класів). Дослідження проводились на основі методик «Дерево» (Д. Лампена), та «Сходинки» (авт. В. Щур).

Варто зазначити, що перед безпосереднім проведенням дослідження з учнями проводилась настановча бесіда, були надані усі необхідні інструкції щодо виконання завдань. Після отримання даних за допомогою ключів до методик (визначення того, які сходинки та чоловічки позначають завищену, адекватну та занижену самооцінку) було визначено кількісні показники щодо рівня самооцінки дітей у кожній з ланок спеціального закладу шкільної освіти, потім визначили 
загальну тенденцію формування самооцінки дітей 3 інтелектуальними порушеннями легкого ступеня.

Рівень самооцінки учнів початкових класів спечіального закладу шкільної освіти для дітей $з$ легким ступенем інтелектуального порушенням за методикою «Сходинки»: 73\% учнів початкових класів даного закладу мають завищену самооцінку, 12\% показали рівень адекватного самооцінювання, $15 \%$ - виявили занижену самооцінку. Методика «Дерево» показала, що у 58\% школярів самооцінка завищена, у 24\% - адекватна, і у 18\% - занижена. Виявлено, що такі результати базуються на характеристиках дітей батьками та вчителями, близьким оточенням та обмеженими уявленнями учнів про свою особистість. В цілому, можемо побачити, що самооцінка дітей даного вікового періоду характеризується неадекватністю в бік завищення (див. рис. 1):

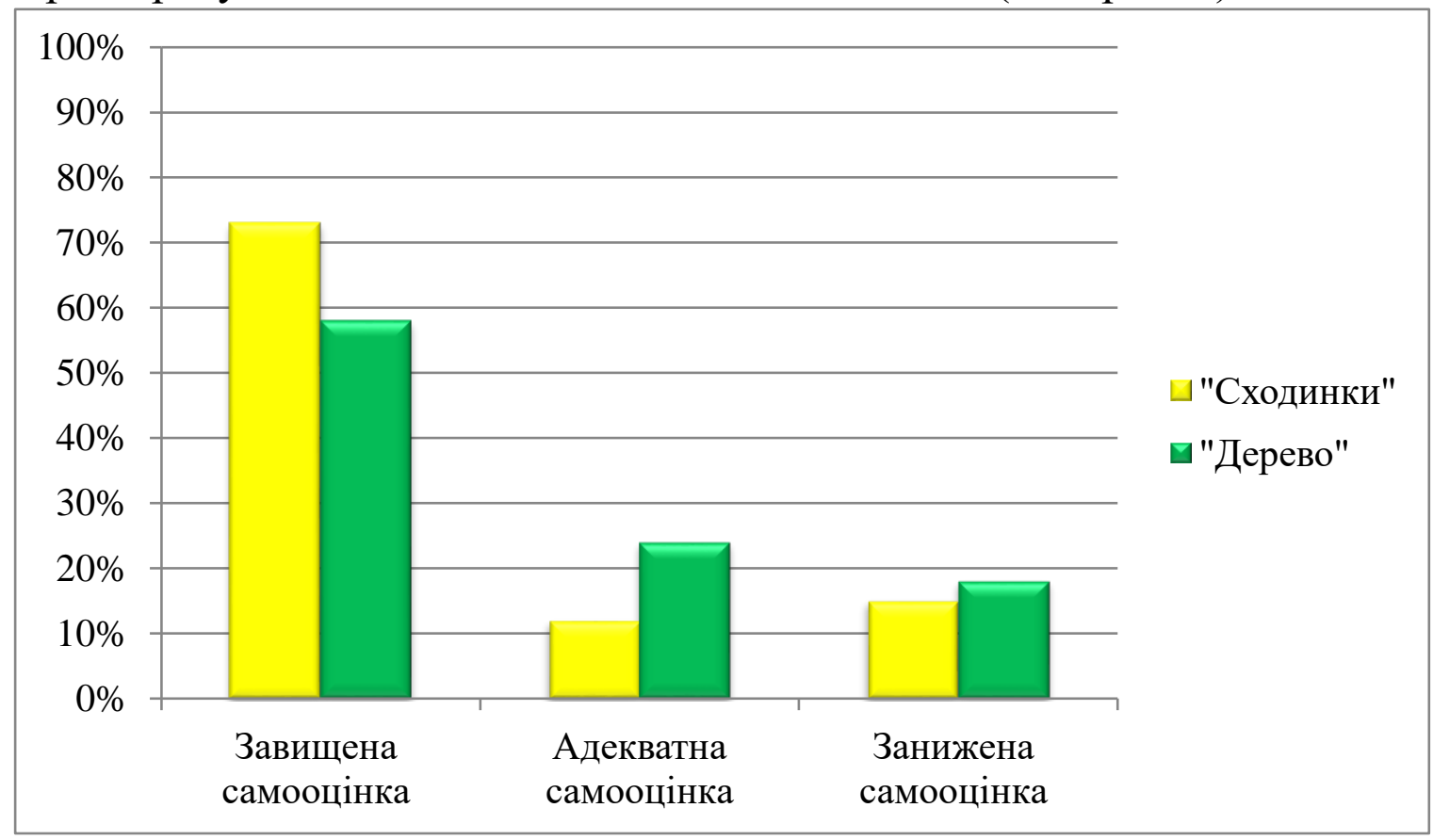

\section{Рис.1. Рівень самооцінки учнів початкових класів 3 інтелектуальними порушеннями}

Рівень самооцінки учнів середніх класів спеціального закладу середньої освіти для дітей з інтелектуальними порушеннями легкого ступеня. Спостерігається значна розбіжність між результатами у процесі використання двох методик: при використанні «Сходинок» бачимо, що у $74 \%$ учнів оцінка завищена, у 20\% - адекватна, і у 6\% - занижена. При використанні тестової методики «Дерево» лише у 26\% оцінка неадекватно завищена, у 16\% - занижена, тоді як у 58\% самооцінка на цьому етапі навчання адекватна. Така розбіжність пояснюється безпосереднім процесом проведення дослідження: у першому випадку дитина виставляє самостійно собі оцінку, при тому у ході оцінювання на неї може впливати перебування у кімнаті друзів, педагогів, які можуть помітити їі оцінку, тоді як за другою методикою діти не знають, який чоловічок яку оцінку позначає. Провівши індивідуальні бесіди з учнями 
більш точними виявляються дані методики «Дерево», адже вони при цьому дали досить аргументовані відповіді, чому вони обрали ту чи іншу оцінку, як вони оцінюють свою роботу у класі, чи приймають участь у житті школи, тощо. Таким чином бачимо, що у середньому шкільному віці діти вже розуміють, що означає «оцінити себе» і рівень їх самооцінки схиляється до більш адекватного (див. рис. 2):

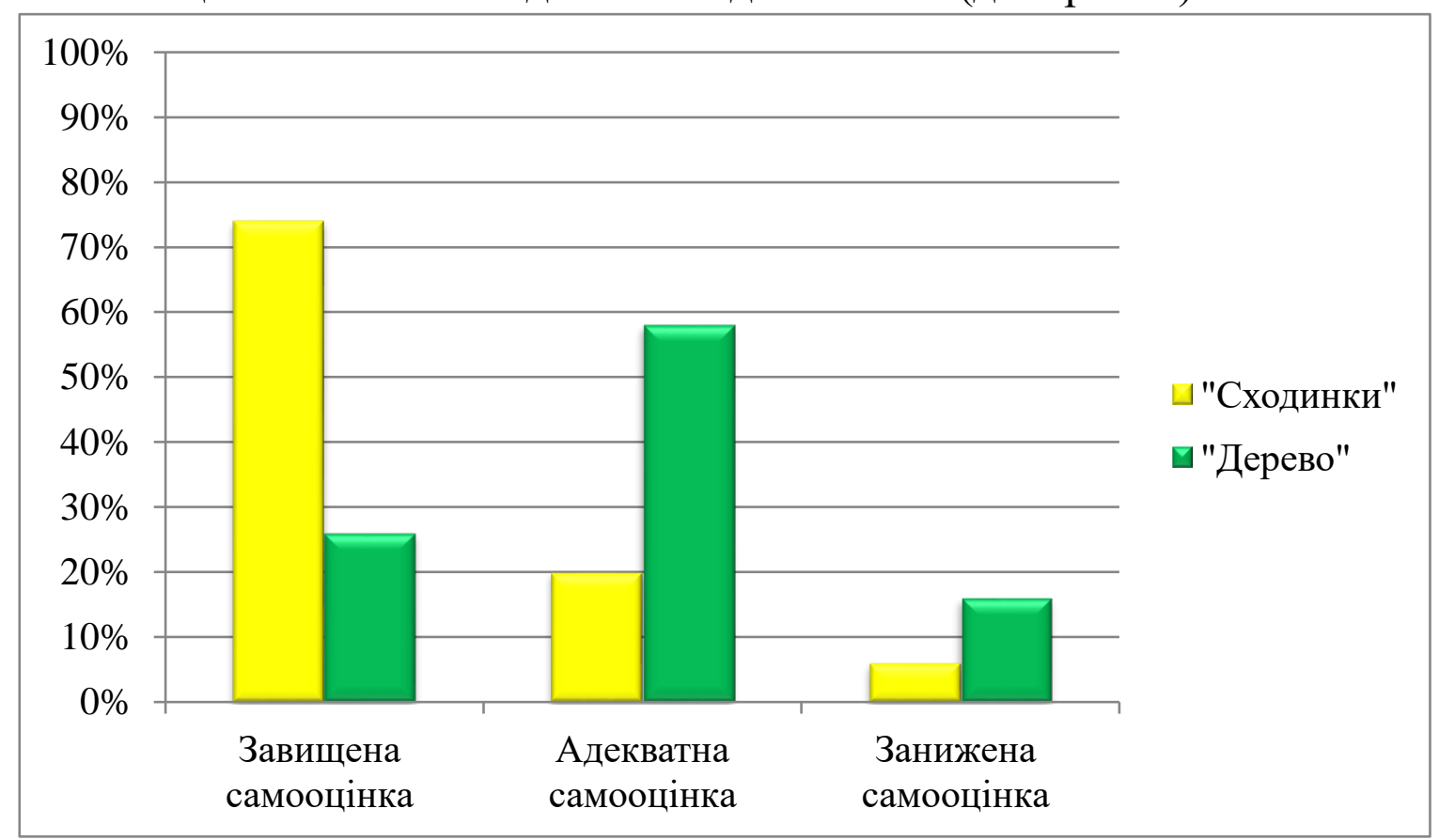

\section{Рис. 2. Рівень самооцінки учнів середніх класів 3 інтелектуальними порушеннями}

Рівень самоочінки учнів старших класів спеціального закладу шкільної освіти для дітей з інтелектуальними порушеннями легкого ступеня: результати проведення першої методики показали, що 86\% школярів мають завищену самооцінку, 7\% - адекватну та ще 7\% занижену. Виконання завдань другої методики дозволили виявити завищену самооцінку у $43 \%$ учнів, адекватну - у $36 \%$, занижена - у $21 \%$. При цьому знову ж необхідно відмітити ті ж розбіжності, які помічені нами під час досліджень дітей середніх класів, що може бути обумовлено тими ж причинами. Варто також зазначити, що у старших класах значно менша кількість опитаних учнів, що також має свій вплив на хід дослідження. В цілому необхідно відзначити, що у цьому віковому періоді спостерігається повернення тенденції до неадекватного оцінювання, зокрема, підвищується рівень заниженої самооцінки - діти соромляться, не хочуть оцінювати себе, важче розповідають про причини такої оцінки, при цьому неохоче ідуть на контакт через усвідомлення того, що вони навчаються у спеціалізованому закладі. По тим же причинам інша частина учнів компенсує дане відчуття завищеною оцінкою та агресією (див. рис. 3): 


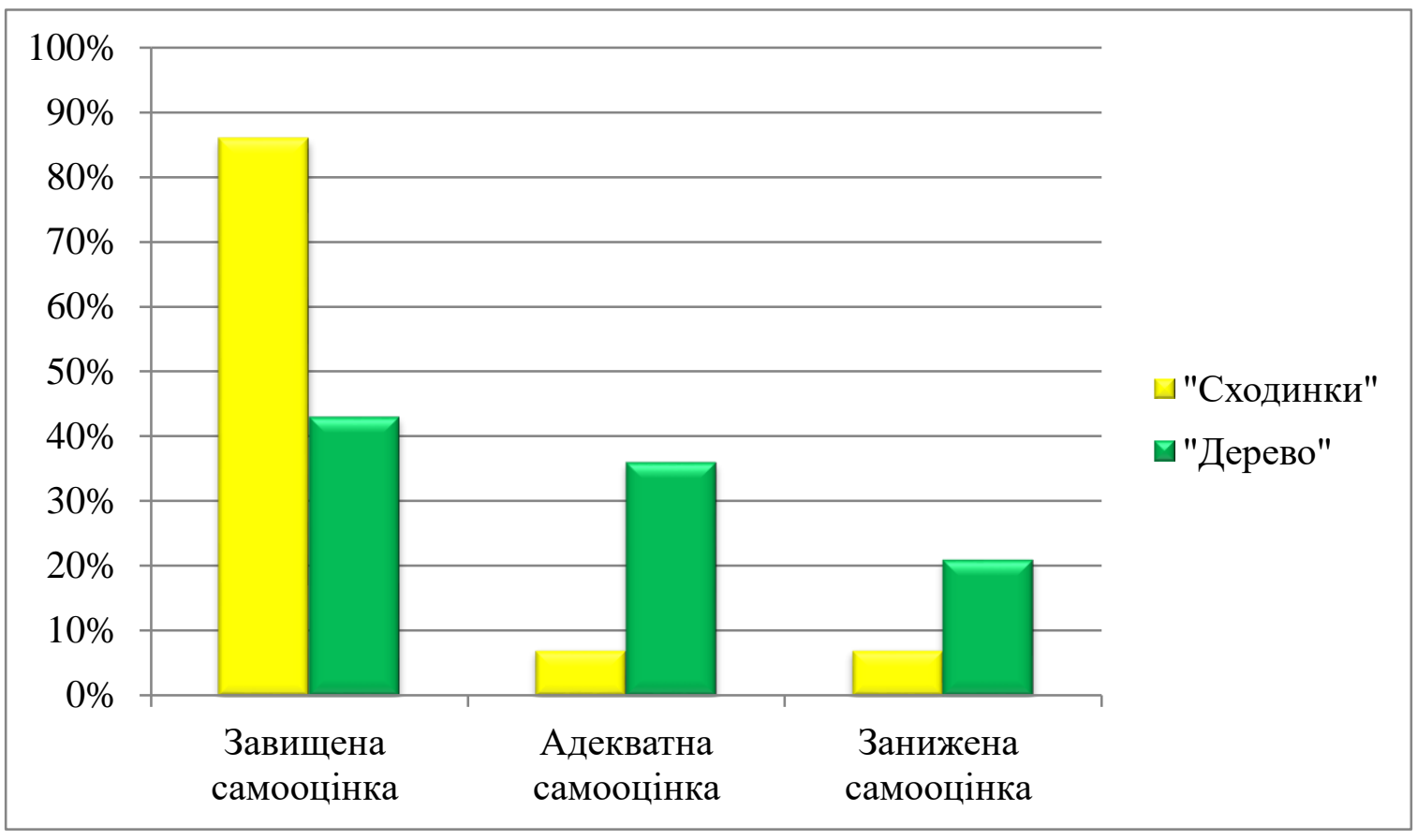

Рис. 3. Рівень самооцінки учнів старших класів 3 інтелектуальними порушеннями

Визначивши рівень самооцінки на кожному з етапів шкільного навчання, визначено загальну тенденцію формування самооцінки учнів 3 інтелектуальними порушеннями за кожною з методик.

За методикою «Сходинки» результат наступний (див. рис. 4):

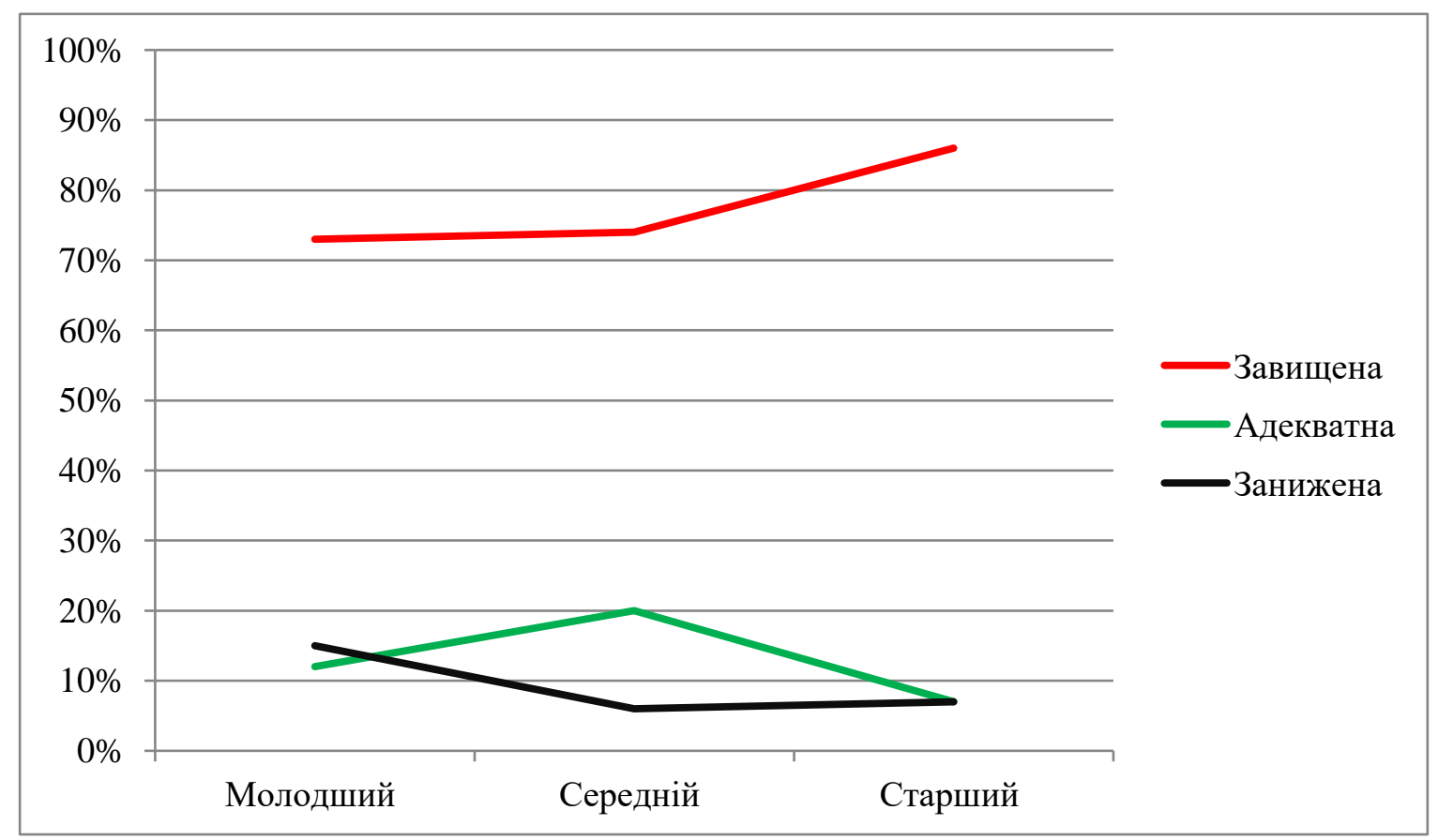

Рис. 4. Тенденція формування самооцінки учнів 3 інтелектуальними порушеннями за результатами методики «Сходинки» 
За даною методикою визначається, що протягом всього процесу навчання дитини в спеціалізованому закладі шкільної освіти у неї переважає завищена самооцінка, яка характеризується збідненими уявленнями про себе, залежністю від думки оточуючих, небажанням приймати активну участь у навчальному процесі. Це відповідь дитини на умови, в яких вона перебуває та на контрастний вплив навчального середовища. Адекватна самооцінка знаходить свій найяскравіший вияв у середньому шкільному віці, тоді як у молодшому шкільному віці знаходиться на низькому рівні, також після проходження середнього етапу - у старших класах - також різко знижується. Знижена самооцінка має загалом нижчий рівень, проявляє себе у молодшому шкільному віці, що може бути пояснено негативною оцінкою оточуючих та однолітків, небажанням оцінювати себе і протестом щодо виконання завдань навчального процесу.

За результатами методики «Дерево» графік тенденції формування самооцінки учнів має дещо інший вигляд (див. рис. 5):

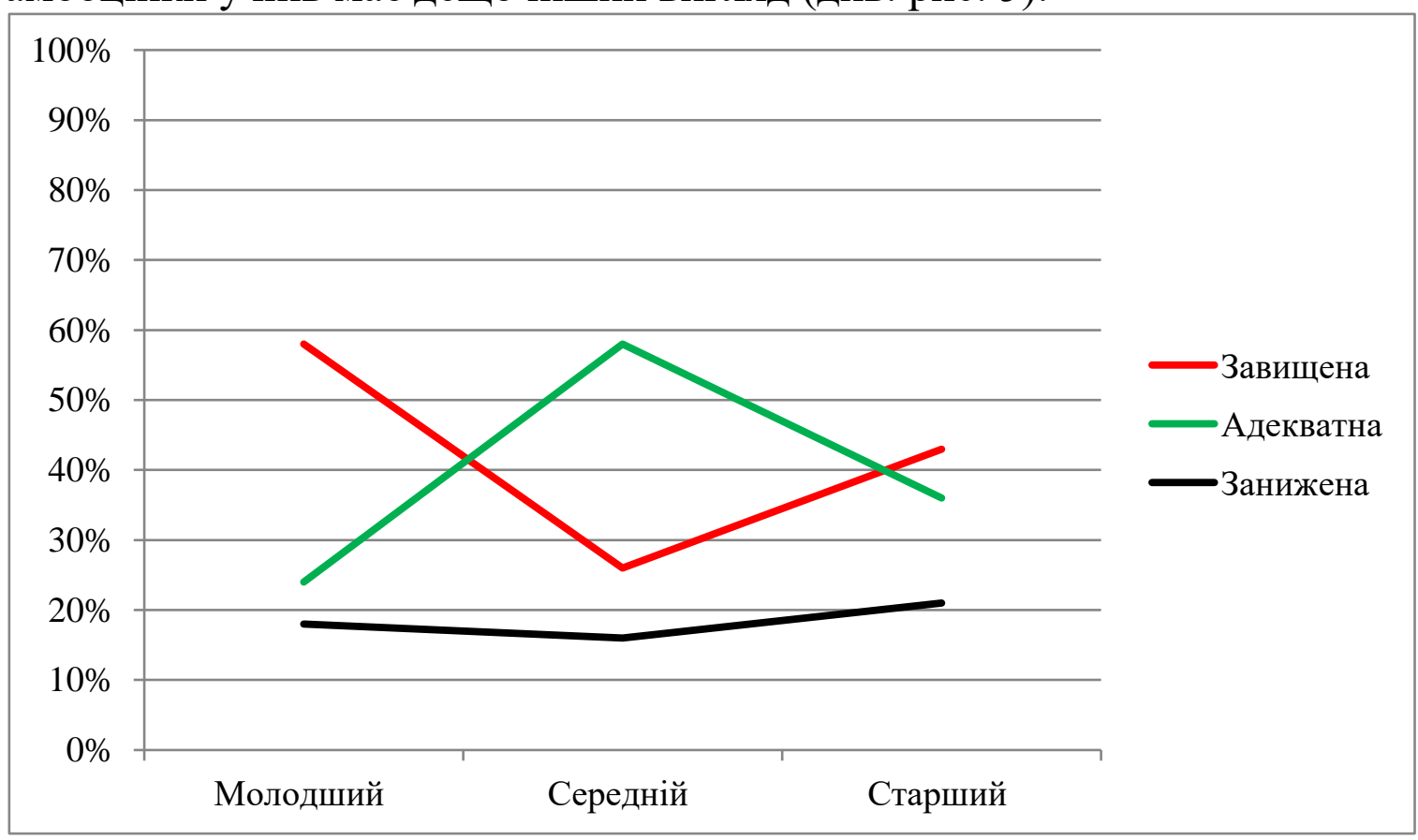

Рис. 5. Тенденція формування самооцінки учнів 3 інтелектуальними порушеннями за результатами методики «Дерево»

За даними цієї методики, формування самооцінки у дітей 3 інтелектуальними порушеннями проходить наступний шлях: на початковій ланці рівень самооцінки знаходиться на неадекватно завищеному рівні, за причин, описаних вище. Під час навчання у 5-x - 8$\mathrm{x}$ класах спеціального закладу середньої освіти у школярів 3 інтелектуальними порушеннями легкого ступеня спостерігається перехід до адекватного оцінювання своєї особистості через оцінювання своєї навчальної діяльності, успішності та взаємодії 3 дорослими та однолітками. Дана тенденція втрачається на завершальному етапі 
навчання - у 9-х - 10-х класах. У цей період навчання у школярів підвищується відсоток заниженої та завищеної самооцінки. Це пояснюється самоусвідомленням учнів у тому, що вони навчаються у спеціалізованому закладі, сором'язливістю, небажанням обговорювати свої особисті проблеми та переживання, іноді - агресивною відповіддю на спроби налагодження контакту. Рівень набутої адекватної самооцінки значно падає.

Висновок. Самооцінка школярів на початковому етапі навчання знаходиться переважно на неадекватно завищеному рівні, що пояснюється нерозумінням учнями суті оцінювання самих себе, залежністю від думки інших. Значно рідше зустрічається занижена самооцінка, практично не знаходить свого вияву адекватне самооцінювання. У середніх класах рівень оцінювання себе досягає найбільш адекватного свого розвитку - саме в цей період діти схильні максимально об'єктивно оцінювати свої можливості, своє навчання та власну поведінку. У своїх судженнях вони опираються на власну оцінку свого навчання, шкільні оцінки, на думку дорослих щодо них. В учнів старших класів спостерігається повернення тенденції до неадекватного самооцінювання - діти не просто розуміють, як оцінити себе, а й розуміють наявну мету дослідження, частіше проявляють сором'язливість, через що намагаються компенсувати ці відчуття неадекватним завищенням чи заниженням своєї оцінки.

Отримані результати визначають тенденцію розвитку «завищена адекватна - завищена/знижена» самооцінка, що було показано нами в графіках. Це підтверджує ті теоретичні результати, які є на сьогоднішній день і які ми використовували під час проведення даного дослідження. Маємо зазначити, що рівень заниженої самооцінки знаходиться на більш стабільному рівні і не має такого яскравого прояву в учнів 3 інтелектуальними порушеннями легкого ступеня, як завищена самооцінка. Такий рівень оцінювання може залишатись у дитини до кінця навчання у спеціальному закладі шкільної освіти, якщо його педагогічним колективом не буде створено сприятливих умов, які спонукатимуть дітей не просто виконувати поставлені навчальні завдання, а й самостійно аналізувати їх, виправляти помилки, робити висновки про наслідки своєї діяльності, що буде своєрідним фундаментом становлення правильного оцінювання власної особистості.

\section{Бібліографія}

1. Ананьев Б. $\mathrm{K}$ постановке проблемы развития детского самосознания / Психология развития: хрестоматия // Под ред. Е. Строганова. СПб.: Питер, 2001. С. 111-115. 2. Зак А. Диагностика основных компонентов творческого мышления //Психодиагностика и школа / Тезисы симпозиума Таллин. 1980. С. 106-108. 3. Матвсєва М. Особливості «Я-образу» розумово відсталих підлітків. Дис.... канд. 
психол. наук. К., 1994. 170 с. 4. Синьов В., Матвеєва М., Хохліна О. Психологія розумово відсталої дитини: підручник. К.: Знання, 2008. 359 с. 5. Шибутани Т. Я-концепция и чувство собственного достоинства // Самосознание и защитные механизмы личности / Самара: Изд. дом «Бахрах», 2008. 46 c.

\section{References}

1. Ananev B. H. (2001). K postanovke problemy razvytyia detskoho samosoznanyia. Psykholohyia razvytyia: khrestomatyia [Tekst]. red. E. Strohanova. SPb: Pyter, 111-115. 2. Zak A. Z. (1980). Dyahnostyka osnovnykh komponentov tvorcheskoho myshlenyia [Tekst]. Psykhodyahnostyka y shkola. Tezysy sympozyuma Tallyn, 106-108. 3. Matvieieva M. P. (1994). Osoblyvosti «Ia-obrazu» rozumovo vidstalykh pidlitkiv. Dys.... kand. psykhol. nauk: K., 170. 4. Synov V. M., Matvieieva M. P., Khokhlina O. P. (2008). Psykholohiia rozumovo vidstaloi dytyny: pidruchnyk. V. M. Synov, M. P. Matvieieva, O. P. Khokhlina - K.: Znannia, 359. 5. Shybutany T. (2008). Ya - kontseptsyia y chuvstvo sobstvennoho dostoynstva. Samosoznanye y zashchytnye mekhanyzmy lychnosty. Samara: Yzd. Dom «Bakhrakh», 46.

Received 08.11.2019

Accepted 08.12.2019

\section{УДК: 616.28-008.14-053.4/.5:616-089.843-031.61:611.851 \\ DOI 10.32626/2413-2578.2020-15.186-198}

О.М. Ткач

oxana77tkach@ukr.net

https://orcid.org/0000-0001-8387-8465

\section{ОСОБЛИВОСТІ НАДАННЯ ЛОГОПЕДИЧНОЇ ДОПОМОГИ ДІТЯМ $З$ КОХЛЕАРНОЮ ІМПЛАНТАЦІЕЮ}

Відомості про автора. Ткач Оксана, кандидат педагогічних наук, старший викладач кафедри логопедії та спеціальних методик факультету корекційної та соціальної педагогіки і психології Кам'янецьПодільського національного університету імені Івана Огієнка. У колі наукових інтересів: методологічні та методичні аспекти організації роботи 3 дітьми зі складними та комплексними порушеннями психофізичного розвитку, проблематика подолання системних порушень мовлення, формування семантичної складової мовленнєвої системи. 